\title{
反すう動物において飼料の惹沸処理が，その栄養価值に 及ぼす影響
}

VI. 大豆粕乞尿素の第一罥内摷発性脂肪酸産生に及洔す影響について

\author{
小島洋一**.川島良治・上坂章次*
}

京都大学满学部，京都市 606

(1972.12.16受付)

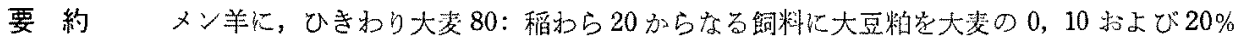

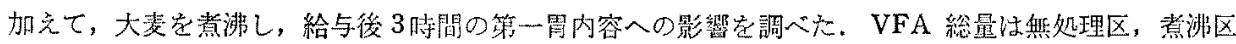

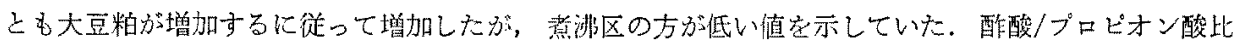
は大豆粕添加によって小さくなったが，者沸区にないては低下が小さかった．乳酸量は大麦の堂沸によ

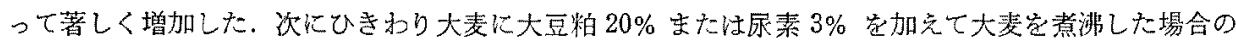

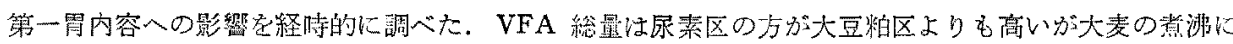
よってVFA 増加の程度は低くなり，また酶酸/プロピオン酸比は大豆粕区の方が尿素区上りる大きく， からいずれも普沸大类の場合には無处理に比して低かった。
\end{abstract}

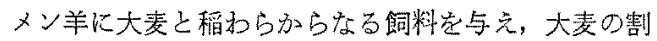
合を 20 から $80 \%$ まで $10 \%$ ずつ段階的に変化させると， 20 和ら $40 \%$ までは大麦の制合が增す従って VFA 総 量が增加し酶酸/プロピオン酸比が小さくなるが，50\% 定越すとVFA 総量は隇少し，60\% を越す酷酸/プロピ オン酸比が大きく就た。宋た大麦家劣沸すると，この 攧向がさらに著しくなった。しかし，尿素学加えると， 大麦の増加または㷛沸処理によって迊るVFA 総量の隇 少, 酩酸/プロピオン酸比の上暈をおさえることが出来 だ!。この試験では大麦の割合の多い場合に，大豆粕を 添加した場合の第一胃内容への影響を検討し，さらに大 豆粕および尿素を加えた飼料を与えて，両者の第一胃内 容への影響の比較花行なった。

\section{試 験 方 法}

\section{第 1 試験}

去勢成メン羊 6頭(体重 27.7 35.5 kg)を用い，6(区)

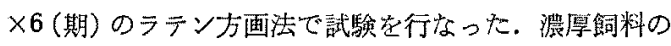
楧成は第 1 衣以示すごとくで，大豆粕空無添加，10\%， $20 \%$ 添加区について，浱厚飼料の $80 \%$ しめる大麦定， 前回の報告2》と同樣の方法で堂沸した区と無処理の区合 計 6 区からなっている。またこれら㲚厚䝭料に $3 \mathrm{~cm}$ に 細切した稲わらを源厚姛料の $1 / 4$ 量加えたものを， 1 日

\footnotetext{
* 現在: 全圂和牛登録協全
}

** 現在: 京都府立大学撗学部

日畜会報，44，(12)：593-597。
第 1 表 第 1 試験の赈厚飼料の区分

\begin{tabular}{|c|c|c|c|}
\hline 区 & $\begin{array}{l}\text { 大豆粕 } \\
\text { 無添加区 }\end{array}$ & $\begin{array}{c}\text { 大豆粕 10\% } \\
\text { 添加区 }\end{array}$ & 大豆粕 $20 \%$ \\
\hline $\begin{array}{l}\text { 濃 } \\
\text { 䃒 }\end{array}$ & $\begin{array}{c}\text { ひきるり大斐 } \\
20\end{array}$ & $\begin{array}{c}\text { 大豆粕 } 10 \\
\text { d装 } \\
10\end{array}$ & 大豆粕 \\
\hline $\begin{array}{l}\text { 飼 } \\
\text { 料 }\end{array}$ & ひきわり大麦 & $\begin{array}{c}\text { ひきわ大麦 } \\
80\end{array}$ & ひき加り大麦 \\
\hline 100 & $\begin{array}{l}\text { (繁沸処理) } \\
\text { (無 処 理) }\end{array}$ & 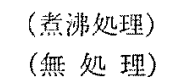 & $\begin{array}{l}\text { (劣沸処理) } \\
\text { (無 好理) }\end{array}$ \\
\hline
\end{tabular}

当り体重の $3 \%$, 朝多等分に与光た. 水注自由に领ませ た。用いた飼料の一般組成は第 2 表に示寸通りである。 これらの飼料で 7 日間予供跼育の後, 3 日間にわたり朝 の給飼の 3 時間後にカテーテルにて第一胃液の採取它行 ない。だちも $\mathrm{pH}$ ネターにて $\mathrm{pH}$ を測定した後, 飽 和昇录水 1,2 滴加元て分析岳で $-20^{\circ} \mathrm{C}$ 亿保存した。 VFA 総量蒸留法で VFA 組成は PACKETT, MCCUNE ${ }^{8)}$ の方法, 乳酸は BARKER, SUMMERSON 法4), フンモニフ 態窒素法微量拡散法到にて測定した。

第 2 試䮦

去勢成メン羊 4 頭(体重 $26.1 \sim 36.5 \mathrm{~kg}$ ) 老用い，4(区) ×4 (期)のラテン方格法で行なった. 第 1 試験の大豆粕 無添加区之同じ飼料水素をひきわり大考の $3 \%$ 加元て 無処理一尿素区とし，無処理一大豆粕区に注大豆粕 $20 \%$

1973. 12 
小島・川島・上坂

第 2 表 試験飼料の一般組成（\%)

\begin{tabular}{|c|c|c|c|c|c|c|}
\hline & 水 分 & 粗蛋白質 & 粗脂肪 & 粗縰維 & 可洽無窒素物 & 粗兏分 \\
\hline ひきわり大麦 & 13.6 & 10.4 & 1.8 & 5.6 & 67.0 & 2.2 \\
\hline わ & 11.5 & 6.5 & 2.0 & 36.7 & 29.5 & 13.7 \\
\hline 大 豆 粕 & 13.2 & 45.6 & 1.5 & 5.2 & 30.1 & 4.4 \\
\hline 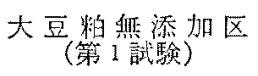 & 13.2 & 9.6 & 1.8 & 11.3 & 59.6 & 4.5 \\
\hline $\begin{array}{c}\text { 大豆粕 } 10 \% \text { 添加区 } \\
\text { 第 } 1 \text { 試験) }\end{array}$ & 13.2 & 12.4 & 1.8 & 11.4 & 56.5 & 4.7 \\
\hline 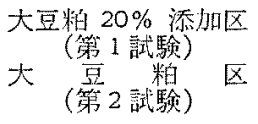 & 13.1 & 15.3 & 1.8 & 11.4 & 53.5 & 4.9 \\
\hline 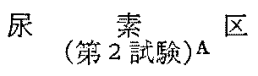 & 12.4 & 15.3 & 1.7 & 10.6 & 55.8 & 4.2 \\
\hline
\end{tabular}

A：尿索は粗蛋白質 $280 \%$ として換算した。

第 3 表 第 1 試験の節一胃液の VFA その他の組成A（第 1 試験）

\begin{tabular}{|c|c|c|c|c|c|c|}
\hline & \multicolumn{2}{|c|}{ 大豆粕無添加区 } & \multicolumn{2}{|c|}{ 大豆粕 $10 \%$ 添加区 } & \multicolumn{2}{|c|}{ 大豆粕 $20 \%$ 添加区 } \\
\hline & 無処理 & 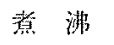 & 無処理 & 煮＼cjkstart沸 & 無処理 & 㵭 沸 \\
\hline VFA 総量 $\mathrm{mol} / \mathrm{l}$ & $63.3^{a *}$ & $51.0^{a}$ & $70.5^{\mathrm{ab}}$ & $58.6^{\circ}$ & $77.7^{\mathrm{b}}$ & $67.8^{\mathrm{ab}}$ \\
\hline \multicolumn{7}{|l|}{ VFA 組成 mol\% } \\
\hline 酢酸 & $65.8^{\mathrm{ab}}$ & $68.2^{\mathrm{a}}$ & $64.7^{\mathrm{ab}}$ & $66.0^{2}$ & $60.2^{b}$ & $65.1^{\mathrm{ab}}$ \\
\hline プロピオン酸 & $22.6^{2 \mathrm{~b}}$ & $18.4^{2}$ & $22.2^{\mathrm{ab}}$ & $20.0^{3}$ & $27.7^{\circ}$ & $21.0^{2 \mathrm{~b}}$ \\
\hline 酪酸 & 9.6 & 11.4 & 10.9 & 11.1 & 8.1 & 12.0 \\
\hline バレリアン酸B & 2.1 & 2.1 & 2.2 & 3.0 & 2.0 & 2.0 \\
\hline 酶酸/プロピオン酸比 & 3.9 & 4.3 & 3.2 & 3.8 & 2.3 & 3.1 \\
\hline $\mathrm{pH}$ & 5.9 & 5.5 & 6.0 & 5.9 & 6.0 & 6.0 \\
\hline $\mathrm{NH}_{3}-\mathrm{N} \mathrm{mg} / 100 \mathrm{~m} l$ & $11.9^{a}$ & $13.5^{\mathrm{a}}$ & $12.9^{\mathrm{a}}$ & $17.3^{\mathrm{ab}}$ & $24.7^{\circ}$ & $22.1^{\mathrm{b}}$ \\
\hline 乳酸 $\mathrm{mg} / 100 \mathrm{~m} l$ & $64.0^{\circ}$ & $17.38^{d}$ & $13.3^{\mathrm{e}}$ & $114.6^{\mathrm{d}}$ & $29.3^{\mathrm{ec}}$ & $111.5^{\mathrm{d}}$ \\
\hline
\end{tabular}

A：各值は $6 \times 3$ サンプルの平均值である.

B：イソーバレリフン酸む含む

*：異るフルファベッドを有するまのの間に有意差があること定示している。

$\mathrm{a} \mathrm{b}$ 間 $\mathrm{P}<0.05$

$c \mathrm{~d}$ 間 $\mathrm{P}<0.01$

$\mathrm{d}$ e 䦓 $\mathrm{P}<0.01$

$c$ e 䦓 $\mathrm{P}<0.05$

添加区と同じものを与えた。なた第 1 試験と同様に澺沸 処理をほどこし，おのおの羔沸一尿素区，堂沸一大豆粕 区とした．飼料蝴多等分に 1 日当り体重の $2.7 \%$ 究与. えその一般組成㤬第 2 表に示すごとくで西る。これらの 飼料で 7 日間予䧿飼姢後， 8 日，10日，12 日目に朝の 給飼前と給飼後 $1 ， 3 ， 6$ 時間に第一胃液をカテーテルに て探取しこれ空 1 期とした。煮沸処理方法，測定項目な ぞは第 1 試験と同様である.

\section{結果}

第 1 試験の結果は節 3 表に示す通りである。第一胃内
VFA 総量汸，無処理区，劣沸区之もに大豆粕の含量が 增加寸るに往って增加し，大豆粕 $20 \%$ 添加無処理区と 大豆粕潕添加無処理区, 大豆粕無添加堂沸区, 大豆粕 $10 \%$ 添加煮沸区之の間に有意差 $(\mathrm{P}<0.05)$ が只られた. すべて煮沸区では無処理区よりるかなり低くなっている が，各区に括いては有意な差ではなかった。しかし全体 を総合した平均值間(無処理： $70.5 \%$ ，煮沸：59.1\%)に

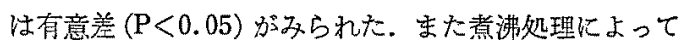
各区とる酶酸の割合が增加し，プロピオン酸の割合が減 少しこの傾向は大豆粕 $20 \%$ 添加区において著しかった. 第一胃内 $\mathrm{pH}$ は大豆粕無添加区で劣沸処理により低下し 


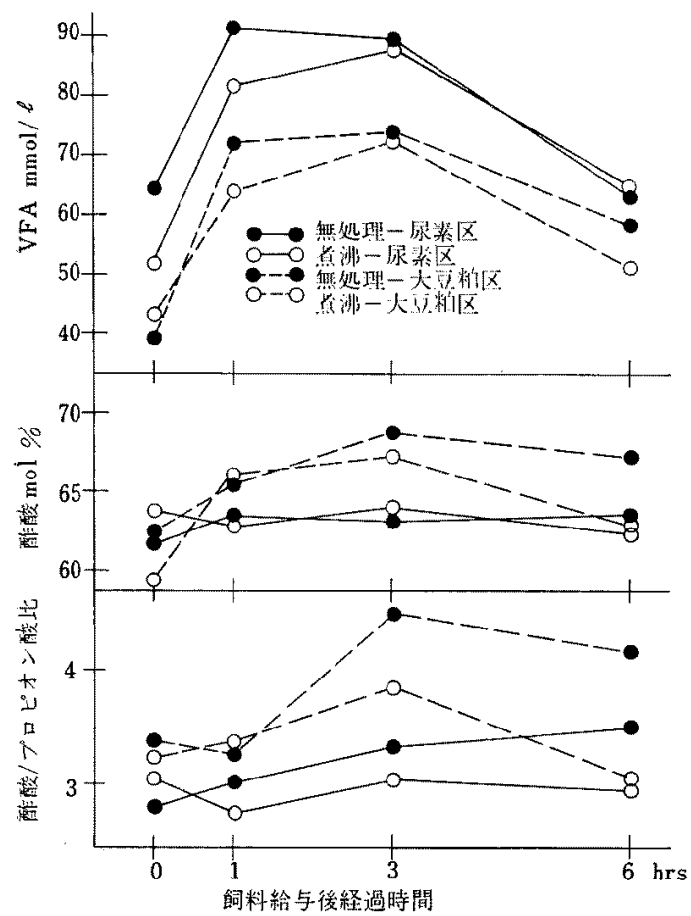

第 1 図 第一胃内 VFA の経時的变化

たが有意な差ではなかった。第一胃内フンモニフ含量 は，大豆粕添加量が多くなるに従って高くなり大豆粕 $20 \%$ 添加区以外は繁沸処理によって高くなる傾向がみ られた．第一胃内乳酸含量以各区之も煮沸処理によって 著しく增加しいずれも無処理の数倍の値を示していた。 $(\mathrm{P}<0.01)$

第 2 試呀の第一胃内 VFA 総量, 䣷酸, 酢酸/ブロピ オン酸比, アンモニフ態空素量および乳酸含量の各期, 8 日，10日，12 日目の平均值を各々図示士れば第 1 因打 よび第2 罒のごとくである.

第一胃内 VFA 総量（第1图）は，いずれの時間にお いてる尿素区が大豆粕区よりも高い傾向があり，とくに 給飼後 1 時間では無処理尿素区之無処理一大豆粕区間に 有意差 $(\mathrm{P}<0.05)$ がみられ，3 時間後で蛙無処理区，劣沰 区ともに尿素区が大豆粕区上りも有意 $(\mathrm{P}<0.05)$ 亿高加 った。第一胃内酶酸怯尿素区に抢いては給飼後の時間経 過によってもほとえど変化がみられず，また劣沸の有無 亿よっても差はみられない。大豆粕区（無処理十堂沸）

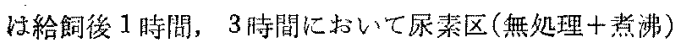
より高くなっており $(\mathrm{P}<0.05)$ とくに 1 時間後において 惊堂沸区間に，3時間後に無処理一大豆粕区に対して無 贬理一尿素区㧍上び煮沸一尿㵖区の間 $(\mathrm{P}<0.05)$ ，なた

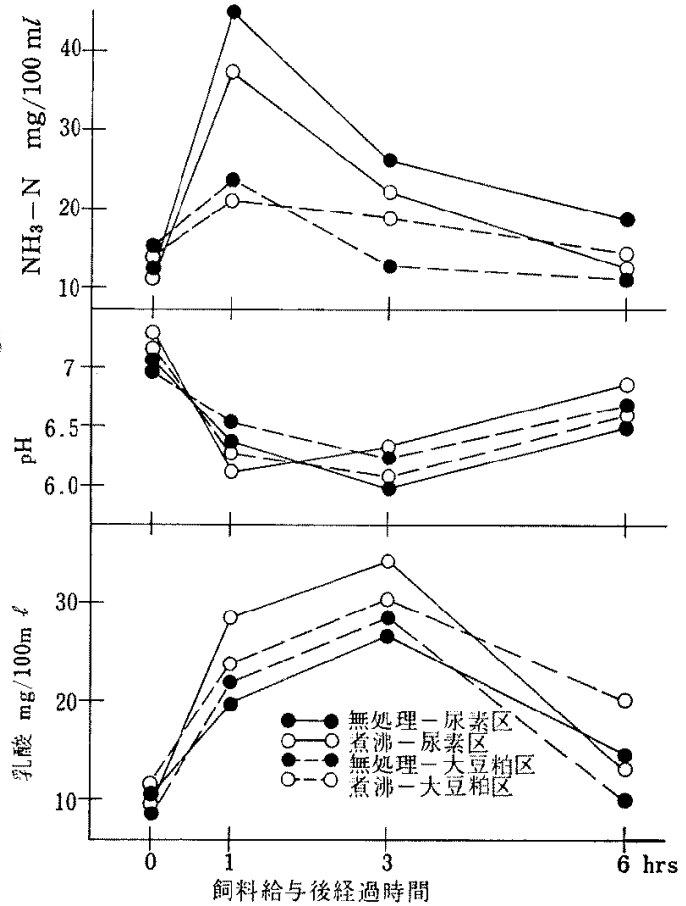

第 2 图 第一䁌内アソモニフ能空素 $\left(\mathrm{NH}_{3}-\mathrm{N}\right), \mathrm{pH}$, 乳酸の経時的変化

6 時間後に扮いては大豆粕区で煮沸処理により有意 $(\mathrm{P}<0.05)$ に低くなっていた。大豆粕区で粭飼後 3 時間 で学沸処理に上り酶酸の割合が低下する傾向があるが， これは第 1 試験と異る結果であった。酢酸/プロピオン 酸比 (第 1 図) は飼料給与前, 給与後 1,3 時間で尿素区 の方が大豆粕よりも低い值を示しており，給飼後 3 時間 で，無処理一大豆粕区と無処理一尿素区，熱沸一尿素区 の間に有意差がみられた。尿素区に沶いて 1，3，6時間， 大豆粕区では 3，6 時問に，煮沸に上って低下する傾向 がみられ，とくに 3 時間後において注大豆粗区，6時間 後に扣いては大豆粕区，际素区の雨区において堂沸処理 により有意 $(\mathrm{P}<0.05)$ に低下していた，また給眗後 1 時 間に执いて大豆粕区上り尿禁区の方が有意 $(\mathrm{P}<0.05)$ に 高く, 粭哴後 3 㭙間で無処理区間飞有意差 $(\mathrm{P}<0.05)$ が あった他怯有意差は及上められなかった。第一胃内 $\mathrm{pH}$

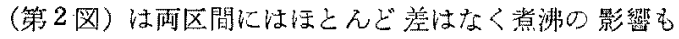
影著でなかった。第一胃内乳酸含量（第 2 図）恰給飼後

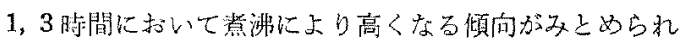
たが，第 1 試験におけるような著しい增加ではなか。 た. 


\section{小自・川自・上坂}

\section{考察}

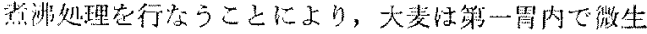

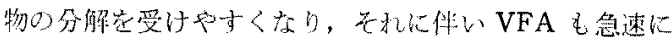

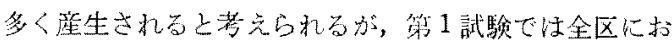

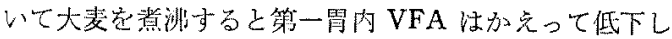
ている．前試驗1の結果とあわせて考党ると者洲赺理し

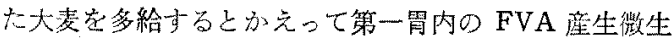

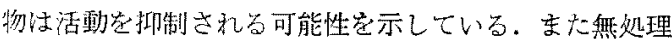
扰よび竟沸した場合ともに大豆粕の增加に伴って增加す る傾向が多られ，とくに大豆粕 20\% 添加堂沸区では大 豆粕無添加無処理区上り高い倠向がある。このここは煮 洲処理に上るVFA 総量の低下が大豆粗源加によってい

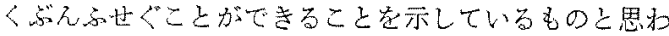
れる。C CHOU and W ALKER $\left.{ }^{6}\right)$ 注第一胃内微生物体の合成 のための十分な窒素源の掑取がなけ犳ば易利用性炭水化 物の発醭利用がうまく行なわ机ないことを報告している こと加ら，急速な発醉に必要な窒素源として大豆粕が利 用されているのかも知れない，そこで大豆粕を㴽加した 区に执い，淩娜処理によりVFA 総量が低くなるの は。鳘素源上しての大豆粕の量が少ないためか，また怔 大豆粕が煮浙された大麦の急速な発醉に即応して利用さ れないためかと推察された，VFA 組成は，大豆粕の添

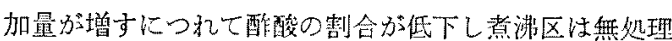
区よりその割合が高くなる傾向があった。同様に大豆粕 定添加すると酢酸/プロピオン酸比が低下し者波すると 高くなっている，乳酸については煮沸处理により著しく 高くなったが $\mathrm{pH}$ ，乳酸ともに無処理では大豆粕添加の 影響以みられないが，煮娜処理すると大豆粕添加によ。 て $\mathrm{pH}$ は上昇し，乳酸はいくぶん低下する傾向にある。 以上のこ゚とく大麦多給封に㧍ける大豆粕の添加が VFA 産生を促進し，酶酸/プロピオン酸比を低下させる役割 をはたすことをみとめた、第 2 試験て，VFA 総量は給 铜後 1 時間で大豆粕区，尿素区ともに蒸沸処理により低 下しているがその後はあまり差はみられない。また层䕀 区の方が大豆粕区上りも一様にその值が高くなっている.

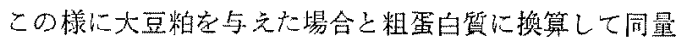
の尿素安与えた場合とでは，尿装を与えたすが VFA 総 量は高くなっており，さらにVFA 組成における比較と あわせると，大麦多給およびその者渄処理による第一型 内でのでんぷえ貿の急激な発醉に対して大豆粕よりも尿 素の方が VFA 産生をらながし，酶酸/プロピオン酸比 を低下させる働きをもつのではないか子考党られる，易 利用性琹索の件給は，微生物の最通の活動を保つために 必項であるここが JOHNSON ら
て報告されており，また BYRANT， and ROBINSON" は第 一霄内 Bacteria の生青にはフンモニフが必要であるこ と, Lewis and MCDonald ${ }^{10)}$ ，LEWIS ${ }^{11}$ および LITTLE ら 12 注易利用性蛋白質が存在すると炭水化物の利用が高 まったこと在報告しており，このことから大豆粕区より 尿素区の方が効果がみられたのは第一胃内で尿素か，易 利用性盈白質と同様にアンモニアに急速に分解されたこ とによるものと考元られる。ただ第 1 試験と第 2 試験に

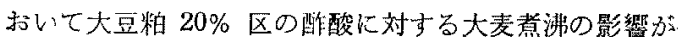
逆にあらわ秃ている。实大第 2 試験に打いては，大豆粕 区で者洲処理しても第1訨験のように乳酸の著しい增加 がみられない。この理由は，第 1 試駰で第 2 試験より 子体重当り飼料粭与量が多く繁処理においてすで乳酸 フシドーシスが起りやすい状態にあり龺沸処理により一 挙に乳酸フシドーシスになったからではないかと考光ら れる.第 2 試験で第 1 試験上りもいく心゙え少なく飼料定 与光たが，これはかなりの残食がみられたためである。 その理由性明らかではないが，第 2 試験は 6 月という動 物にとって季節的には悪条件下で行なわれたことと，経 時的なカテーテルによる第一胃液の採取などによるス卜 レスが原因となっているのかる知机ない。

以上のことから穀類多給時にお污る煮娜処理の第一胃 内 VFA 総量拉よび組成に対する影響は，同時仙給与さ

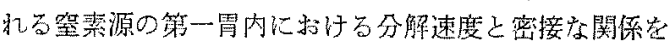
有するものと推察される。

\section{文献}

1）小島洋一一川島良治・上坂章次，日畜会報 42:7986. 1971.

2）小島洋一・㑑良治・上坂章次，日蓄会報 40：511. 1969.

3) Packet, L. V., and R. W. McCune, Appl Microbiol 13: 22-27. 1965.

4) Barker, S.B., and W.H. Summerson, J Biol Chem 138: 535-554. 1941.

5) Conway, E.J., Microdiffusion Analysis and Volumetric Error, 3rd ed. London Crosby Lockwood and Son Ltd. 1961.

6) Chou, K.C., and D.M. WALKer, J Agric Sci 62: 7-13. 1964.

7) Johnson, B.C. T. S. Hamilton, W. B. Robinson, and J.C. Garey, J Anim Sci 3: 287-298. 1944.

8) Burrough, W, J. Long, P. Gerlaugh, and R. M. BethKE, J Anim Sci 9: 523-530. 1950.

9) Byrant, M. P., and I. M. RoBinson, Appl Microbiol 9: 96-102. 1961.

10) Lewis, D., and I.'W. McDonald, J Agric Sci 51 : 108-118. 1958. 
11) Lewis, D., J Agric Sci 58: 73-79. 1962.

12) Little, C.O., W. Burroughs, and W. Woode,

J Anim Sci 22: 358-363. 1963.

\title{
Studies of the Effect of Cooking on the Nutritive Valuc of Feedstuffs
}

\author{
VI. Effect of the Addition of Soybean Meal or Urea on VFA Production \\ in the Rumen of Wethers Fed High-Barley Ration
}

Yoichi Kojima, Ryoji Kawashima and Shoji Uesaka

Faculty of Agriculture, Kyoto University, Kyoto-shi 606

\begin{abstract}
Six wethers were used and fed the diet, which is equivalent to $3 \%$ of their body weight, consisted of raw or cooked barley $(80 \%)$, rice straw $(20 \%)$ and soybean meal equivalent to 0,10 and $20 \%$ of the barley. Rumen juice was sampled 3 hours after feeding. Total VFA increase of the amount of soybean meal in the diet regardless of raw or cooked barley, however, the VFA value was lower in case of cooked barley diet. Acetate to propionate ratio decreased as the amount of soybean meal in the diet increased and it increased with the cooked barley diet. Next, four wethers were used and fed the diet, consisted of raw or cooked barley $(80 \%)$ and rice straw $(20 \%)$, which is equivalent to $2.7 \%$ of their body weight into which soybean meal ( $20 \%$ of barley) or urea ( $3 \%$ of barley) was added. Rumen juice was sampled $0,1,3$ and 6 hours after feeding. There was consistent trend of higher total VFA value in the animal fed urea-added diet than soybean meal-added diet. Acetate to propionate ratio was lower in the animal fed urea-added diet than the animal fed soybean meal-added diet except the case of 6 hours after feeding. Acetate to propionate ratio generally decreased in the animals fed urea- or soybean meal-added and cooked barley diet. The fact that this effect of cooking on acetate to propionate ratio differed from the result in former experiment based primarily on the change of amount of diet. From the view-point of that the readily available nitrogen is required for the fermentation of large amount of starchy diet, urea has better effects than soybean meal.
\end{abstract}

